\title{
Chemically modified siRNA directed against the KDR gene inhibits the proliferation of breast cancer cells
}

\author{
YIN-LIN GE, JIN-YU ZHANG, XIAO ZHANG, LIN HOU, QUAN LI and MEI-LAN XUE \\ Department of Biochemistry and Molecular Biology, Medical College, \\ Qingdao University, Qingdao, Shandong 266021, P.R. China
}

Received June 13, 2008; Accepted November 7, 2008

DOI: $10.3892 / \mathrm{mmr} 00000072$

\begin{abstract}
Vascular endothelial growth factor receptor-2 or kinase insert domain-containing receptor (VEGFR2/KDR) is secreted by most solid tumors, including breast cancer, and is an important mediator of angiogenesis. To observe the effects of KDR gene expression on cell proliferation and the cell cycle in MCF-7 cells in vitro and in vivo, we used chemically modified siRNA directed against KDR. The results revealed that chemically modified siRNA transfection of the KDR gene effectively inhibited the proliferation of MCF-7 cells, arrested cells in the G1 phase and down-regulated the expression of KDR. In addition, in the progression of cell cycle arrest induced by siRNA, phosphorylated ERK and CDK1 expression was down-regulated $(\mathrm{P}<0.01)$. In vivo, the growth of tumors was visibly suppressed. RT-PCR and the results of immunohistochemistry indicated that KDR mRNA and protein expression was reduced in the excised tumors. In contrast, there were no obvious changes in the control groups. This implies that chemically modified KDR siRNA markedly decreases KDR gene expression and inhibits cellular proliferation in vitro, as well as suppressing tumor growth in a xenograft model. KDR may be a new target for breast cancer treatment.
\end{abstract}

\section{Introduction}

Angiogenesis is a complex process that is essential for tumor growth beyond 1 or $2 \mathrm{~mm}^{3}$. Kinase insert domain-containing receptor (KDR), commonly known as VEGFR2, is one of the best characterized pro-angiogenic factors, playing a critical role in physiological and pathological angiogenesis (1). Via its interaction with VEGF, KDR mediates many key components of angiogenesis, including endothelial cell proliferation, invasion, migration and survival, as well as vessel permeability.

Correspondence to: Dr Yin-Lin Ge, Department of Biochemistry and Molecular Biology, Medical College, Qingdao University, 38 Dengzhou Road, Qingdao, Shandong 266021, P.R. China

E-mail: geyinlin@126.com

Key words: breast cancer, kinase insert domain-containing receptor, RNA interference, small interfering RNA, vascular endothelial growth factor receptor-2
It also plays an important role in the regulation of tumor genesis and development (2-4). In addition to activating KDR on vessels in a paracrine manner, VEGF secreted by tumor cells also activates KDR on itself in an autocrine manner, and directly promotes the growth of tumor cells (5-10). Therefore, by inhibiting the expression of KDR, tumor growth can be suppressed on two levels.

With one million new cases presenting each year, breast cancer is the most common cancer among women and the leading cause of death worldwide in those between the ages of 30 and 70 years $(11,12)$. In human breast cancer, levels of KDR have been correlated with tumor progression and invasion (13). KDR and VEGF are co-expressed in primary breast carcinomas, and their expression is increased when tumors shift to an angiogenic phenotype $(14,15)$. Many investigators are beginning to advocate silencing the gene expression of angiogenic factors as an anti-angiogenic strategy.

RNA interference (RNAi ) is a novel gene therapy technology $(16,17)$ in which $21-25$ nucleotide small interfering RNA (siRNA) duplexes, homologous to the silenced gene, function as sequence-specific RNAi mediators, suppressing the expression of the target gene. siRNA synthesis in vitro is the latest development in RNAi; however, the poor stability and specificity of siRNA in vivo restricts its use (18). Due to this poor stability, siRNA is easily degraded by the nuclease, restricting its application in vivo (19). The main obstacle confronting the application of siRNA to the treatment of disease is finding a way to avoid this degradation. This can be acheived by chemically modifying siRNA effectively and by choosing a suitable transduction system in vivo to promote the transposal of RNAi from in vitro to in vivo studies, from the laboratory to clinical application.

In the present study, we designed and synthesized siRNA that targeted KDR. siRNA was chemically modified in order to strengthen its stability in vitro and in vivo. In vitro, human breast cancer MCF-7 cells were used to investigate the suppression of KDR expression and the growth of cancer cells. In vivo, siRNA was injected into MCF-7 cell tumor xenografts implanted in nude mice, in order to test its resulting anti-tumor potential.

\section{Materials and methods}

Cells and cell culture. Human breast cancer MCF-7 cells were obtained from the Cell Center, School of Basic Medicine, Peking Union Medical College. The cells were cultured in 
DMEM (high glucose) supplemented with $10 \%$ fetal bovine serum (Gibco) at $37^{\circ} \mathrm{C}$ in a humidified atmosphere with $5 \%$ $\mathrm{CO}_{2}$.

Mice. Four-week female BALB/c nude mice were purchased from Slac Laboratory Animal Co. LTC (Shanghai, P.R. China). All mice were cared for in compliance with the guidelines of our institution.

Design and synthesis of siRNA. The published sequence of KDR (GenBank accession no. GI:11321596) was obtained from NCBI. According to the online Free siRNA Design Software and RNA secondary structure analysis software 'structure 4.4', we compared the randomly designed siRNA and the predicted KDR mRNA secondary structure to choose a pair of siRNA that was easily combined. The sequences of the KDR siRNA were: sense 5'-GCCACCAUGUUCUCU AAUAUU-3' and antisense 5'-UAUUAGAGAACAUGG UGGCUU-3'. Meanwhile, a pair of negative control siRNA was designed, the sequences of which differed from the KDR siRNA (siRNAscr, 5'-UUCUCCGAACGUGUCACGUU-3' and 5'-ACGUGACACGUUCGGAGAAUU-3'). The 3'-end of siRNAscr was labeled with fluorescein isothiocyanate (FITC) for transfection rate valuation. Both pairs of siRNA were examined by BLAST to ensure they were not homologous with other genes. In order to strengthen the stability of the siRNA, its sense strand was fluoromodified, while its antisense strand was not. All siRNA sequences were chemically synthesized by Shanghai Genepharma Co. Ltd. (P.R. China).

Cell transfection. FITC-labeled siRNAscr was used to optimize transfection. One day before transfection, cells were seeded in $1 \mathrm{ml}$ of growth medium without antibiotics in a 12-well format so that cells would be $60-70 \%$ confluent at the time of transfection. Different doses of siRNAscr were diluted in $250 \mu 1$ Opti-MEM (Invitrogen, USA) without serum, and the same amount of Lipofectamine 2000 ${ }^{\mathrm{TM}}$ (Invitrogen) was diluted in $250 \mu \mathrm{l}$ Opti-MEM. After incubation for $5 \mathrm{~min}$ at room temperature, the diluted siRNAscr was combined with the diluted Lipofectamine 2000, mixed gently and incubated for $20 \mathrm{~min}$ at room temperature. We then removed the old medium and added $500 \mu 1$ of the complexes to each well. The cells were incubated at $37^{\circ} \mathrm{C}$ in a $\mathrm{CO}_{2}$ incubator for $6 \mathrm{~h}$, then observed under a fluorescence microscope to obtain the best ratio of siRNA and Lipofectamine 2000 for subsequent use.

Growth inhibitory effects measured by MTT colorimetry. MCF-7 cells $\left(4 \times 10^{4}\right)$ were plated in 96-well plates with DMEM in a final volume of $0.1 \mathrm{ml}$. Seven groups were categorized as follows: blank control, media without serum and antibiotics; Lipofectamine control, media with Lipofectamine 2000 only ( $0.5 \mu 1$ per plate); 4 groups of siRNA concentrations of 25,50 , 100, $200 \mathrm{nmol} / \mathrm{l}$; and the siRNAscr group (100 nmol/l). The next day, cells were transfected as above and cultured for $48 \mathrm{~h}$. Subsequently, the cells were incubated in MTT $(5 \mathrm{mg} / \mathrm{ml})$ for $4 \mathrm{~h}$, and their optical density was determined with a microculture plate reader at $492 \mathrm{~nm}$.

Total RNA extraction and PCR reaction. Total RNA was isolated from MCF-7 cells treated with siRNA using TRIzol reagent (Invitrogen) according to the manufacturer's instruc- tions. RNA $(1 \mu \mathrm{g})$ was reverse-transcribed in a $20-\mu 1$ reaction volume with oligo dT primers using a reverse-transcription system (Promega, USA). PCR was carried out in a final volume of $25 \mu 1$ using RNase-free water as negative template control. The regimen for PCR was $5 \mathrm{~min}$ at $94^{\circ} \mathrm{C}$ followed by 35 cycles of $45 \mathrm{sec}$ at $94^{\circ} \mathrm{C}, 45 \mathrm{sec}$ at $64^{\circ} \mathrm{C}$ and $2 \mathrm{~min}$ at $72^{\circ} \mathrm{C}$, with a final 7 -min extension at $72^{\circ} \mathrm{C}$. The reaction was also carried out with GAPDH as an internal control. The KDR and GAPDH primers were: KDR (795 bp) forward 5'-CTGGCATGGTCT TCTGTGAAGCA-3', reverse 5'-AATACCAGTGGATGT GATGCGG-3' and GAPDH (509 bp) forward 5'-CGTGGA AGGACTCATGACCA-3', reverse 5'-TCCAGGGGTCTT ACTCCTTG-3'. Amplified PCR products were densitometrically scanned and analyzed by Tianneng analysis software after gel electrophoresis. The optical density of the products was determined, and KDR/GAPDH was calculated.

Flow cytometric analysis. After treatment with $100 \mathrm{nmol} / \mathrm{l}$ siRNA for $48 \mathrm{~h}$, cells attached to culture dishes were trypsinized and washed in PBS, and then fixed with $70 \%$ ethanol for $24 \mathrm{~h}$ at $-20^{\circ} \mathrm{C}$. Next, cells were washed once with PBS followed by incubation in PBS containing $25 \mathrm{mg} / \mathrm{ml}$ propidum iodide and $200 \mathrm{mg} / \mathrm{ml} \mathrm{RNase} \mathrm{A} \mathrm{for} 1 \mathrm{~h}$ at room temperature in the dark. Stained nuclei were then analyzed using a Becton Dickinson FACScan with 11,000 events per determination.

Western blot analysis. Cells were seeded in 6-well plates and incubated with siRNA as described above. Briefly, 50- $\mu \mathrm{g}$ samples of protein were subjected to $10 \%$ standard sodium dodecyl sulfate-polyacrylamide gel electrophoresis (SDSPAGE) with pre-stained molecular weight markers run in parallel to identify the proteins. The resolved proteins were blotted onto nitrocellulose membranes, and the mAbs antihuman phosphorylated ERK (1:1000 dilution; Sigma), antihuman CDK1 (1:300 dilution; Sigma) and anti-human B-actin (1:2000 dilution; Sigma) were used to localize the corresponding polypeptides on the blots. After extensive washing, the membranes were incubated with IgG-horseradish peroxidaseconjugate antibody (1:3000 dilution; Zhongshan Co.) for $1 \mathrm{~h}$ at room temperature and developed with a Luminol chemiluminescence detection kit (Santa Cruz). Membranes probed for KDR were reprobed for $B$-actin to normalize them for loading and/or quantification errors and to allow comparisons of target protein expression to be made. Protein expression was quantified using a Gel EDAS analysis system (Cold Spring USA Corp.) and Gel-Pro Analyzer 3.1 software (Media Cybernetics).

Animal experiments. In accordance with the literature (20) regarding the establishment of MCF-7 human breast xenografts, mice were administered exogenous estrogen $(10 \mathrm{mg} / \mathrm{kg})$ twice a week by intraperitoneal injection for 2 weeks. MCF-7 cells $\left(5 \times 10^{6}\right)$ in $100 \mu 1 \mathrm{D}$-Hank's were subsequently injected s.c. into the right flank of each mouse. When tumor size reached 5-7 $\mathrm{mm}$ in diameter, mice were divided into 4 groups $(n=5)$ : the blank control group, treated with 5\% glucose only; the transfection agent group, treated with in vivo-jetPEI ${ }^{\mathrm{TM}}$ and $5 \%$ glucose); the low-dose siRNA group, treated with $0.5 \mathrm{mg} /$ $\mathrm{kg}$ KDR siRNA, in vivo-jetPEI and 5\% glucose; and the highdose siRNA group, treated with $1 \mathrm{mg} / \mathrm{kg}$ KDR siRNA, in vivojetPEI and 5\% glucose. In vivo-jetPEI (Poly Plus, France) is 
Table I. Detection of MCF-7 cell proliferation by MTT colorimetry $48 \mathrm{~h}$ after siRNA transfection.

\begin{tabular}{lcc}
\hline $\begin{array}{l}\text { Group } \\
(\mathrm{n}=6)\end{array}$ & $\begin{array}{c}\text { OD value }^{\mathrm{a}} \\
(492 \mathrm{~nm})\end{array}$ & $\begin{array}{c}\text { Inhibition ratio } \\
(\%)\end{array}$ \\
\hline Blank control & $0.726 \pm 0.062$ & - \\
Lipofectamine control & $0.728 \pm 0.041$ & - \\
siRNAscr & $0.695 \pm 0.018$ & - \\
$25 \mathrm{nmol} / \mathrm{l}$ siRNA & $0.628 \pm 0.049^{\mathrm{b}}$ & 13.5 \\
$50 \mathrm{nmol} / 1 \mathrm{siRNA}$ & $0.558 \pm 0.058^{\mathrm{b}}$ & 23.1 \\
$100 \mathrm{nmol} / 1$ siRNA & $0.409 \pm 0.054^{\mathrm{b}}$ & 43.7 \\
$200 \mathrm{nmol} / 1$ siRNA & $0.420 \pm 0.085^{\mathrm{b}}$ & 42.1 \\
\hline
\end{tabular}

A significant reduction was observed upon treatment with 100 and $200 \mathrm{nmol} / 1 \mathrm{siRNA} .{ }^{\mathrm{a}}$ Mean $\pm \mathrm{SD} .{ }^{\mathrm{b}} \mathrm{P}<0.01$ vs. blank control group.

a transfection agent mainly used in vivo. According to the manufacturer's recommendations, the first intratumoral injection was carried out in a final volume of $100 \mu 1$. Intratumoral injections at the same dose were repeated on days $3,6,9$, 12, 15, 18 and 21. Every 3 days, the tumor diameters were measured and their volume $\left(0.5 \mathrm{a} \mathrm{x} \mathrm{b}^{2}\right.$, where $\mathrm{a}$ is the largest diameter of the tumor and $b$ is the smallest diameter of the tumor) was calculated. Tumor volumes were recorded from the second injection (day 3 ). On day 24 , the mice were sacrificed and their tumors were removed. One portion was homogenated for RNA extraction as described above and the other portion was fixed in $10 \%$ formalin for hematoxylin and eosin (H\&E) and immunohistochemical staining.

Histological examination. The formation-fixed tissues were embedded in paraffin wax and sliced into $4-\mu \mathrm{m}$ sections using a rotary microtome, then stained with $H \& E$ for histological examination under a light microscope.

Immunohistochemical staining. Immunohistochemical staining was performed by a two-step method. Anti-mouse KDR mAb (Santa Cruz, USA) at a dilution of 1:300 was used as the primary antibody. The PV6002 kit (Zhongshan-Bio, P.R. China) was used in the second step of staining. Sections were counterstained with haematoxylin and mounted.

Statistical analysis. Results were presented as the mean \pm standard deviation (SD). Differences between means were determined by the unpaired sample t-test. Influx studies were carried out using two-way ANOVA. A probability value of $\mathrm{P}<0.05$ was considered statistically significant.

\section{Results}

Antiproliferative effect of siRNA on MCF-7 cells by MTT colorimetry. The absorption values for MCF-7 cells treated with each concentration of KDR siRNA were significantly lower than those of the blank control group $(\mathrm{P}<0.01)$, while no effect was observed in the siRNAscr and Lipofectamine groups. To determine the effect of siRNA concentrations on the


Figure 1. KDR mRNA expression in MCF-7 cells transfected with siRNA measured in vitro. For RT-PCR, RNase-free water was used as a negative PCR control and GAPDH as a control. Lane 1, RNase-free water; lane 2, $50 \mathrm{nmol} / 1$ KDR siRNA group; lane 3, $100 \mathrm{nmol} / \mathrm{KDR}$ siRNA group; lane 4, $200 \mathrm{nmol} / \mathrm{l}$ KDR siRNA group; lane 5, transfected with siRNAscr group; lane 6, transfected with Lipofectamine group; lane 7, non-transfected group. Compared with the control group, the expression of KDR mRNA was effectively downregulated in groups treated with $\mathrm{KDR}$ siRNA in vitro $(\mathrm{P}<0.01)$.

inhibition of cancer cell growth, we evaluated the effect of different concentrations on the KDR mRNA molecule. The results revealed that the transfected KDR siRNA markedly inhibited the growth of the MCF-7 cells at concentrations of 100 and $200 \mathrm{nmol} / \mathrm{l}$. However, the OD values of the $100 \mathrm{nmol} / \mathrm{l} \mathrm{siRNA}$ group were not significantly different from those of the $200 \mathrm{nmol} / 1$ siRNA group ( $>>0.05)$, suggesting that the cellular suppressive effect of siRNA is only dose dependent within a certain scope; with certain concentrations, the silencing effect was not increased. The OD values of each group and the inhibition ratios are listed in Table I.

Down-regulation of KDR $m R N A$ expression in vitro. RT-PCR was performed to analyze KDR mRNA levels. The relative mRNA expression of KDR/GAPDH was significantly lower in the 50, 100 and $200 \mathrm{nmol} / \mathrm{l}$ siRNA groups than in the blank control or Lipofectamine control groups $(\mathrm{P}<0.05)$. Additionally, the relative mRNA expression of KDR/GAPDH was much lower in the 100 and $200 \mathrm{nmol} / \mathrm{l}$ siRNA groups than in the $50 \mathrm{nmol} / 1$ siRNA group $(\mathrm{P}<0.05)$. There was no marked difference between the 100 and $200 \mathrm{nmol} / 1$ siRNA groups ( $\mathrm{P}>0.05)$. These results indicate that KDR mRNA expression was strongly down-regulated after siRNA transfection; the same result was obtained by MTT colorimetry (Fig. 1).

Changes in the cell cycle. Since siRNA affects cell proliferation, we assessed the effect of siRNA on cell cycle progression. As shown in Fig. 2, flow cytometric analysis indicated that MCF-7 cell growth was arrested in the G1 phase of the cell cycle and decreased in the $\mathrm{S}$ phase (DNA synthesis phase) following KDR siRNA treatment. Treatment with siRNAscr had no effect on the cell cycle, while treatment with KDR siRNA resulted in significant growth arrest in the G0/G1 phase. The effect appeared after $48 \mathrm{~h}$ of 

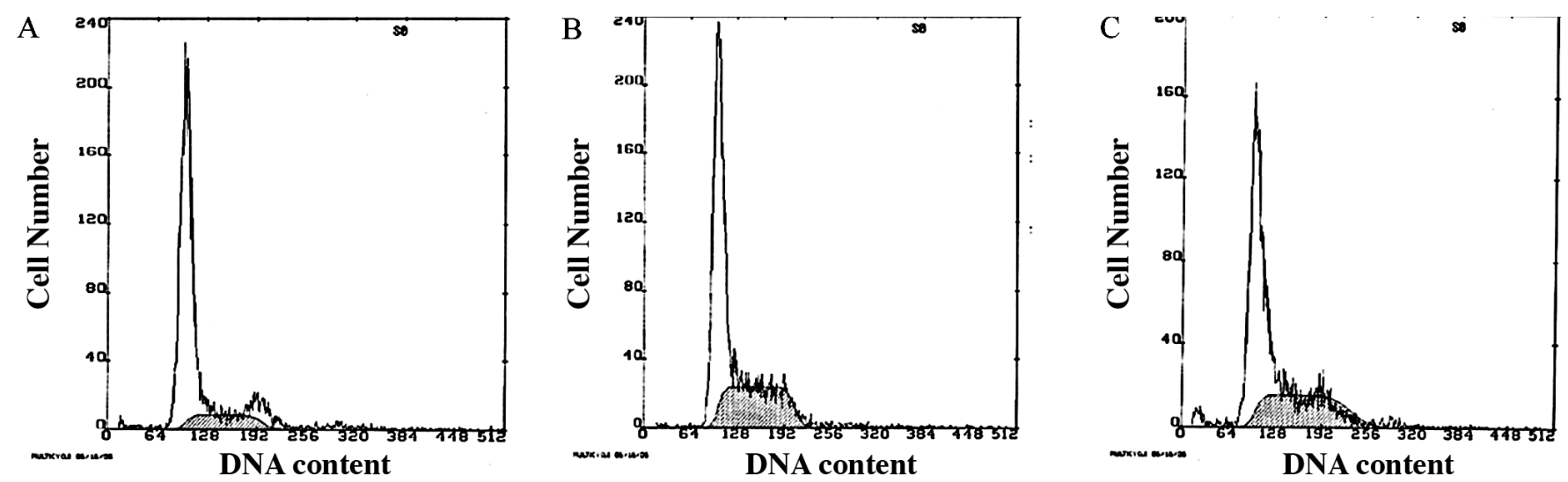

Figure 2. The effect of siRNA transfection on the cell cycle of MCF-7 cells. (A) KDR siRNA group; (B) siRNAscr group; (C) blank control group. Flow cytometric analysis indicated that MCF-7 cell growth was arrested in the G1 phase of the cell cycle and decreased in the S phase (DNA synthesis phase) following KDR siRNA treatment.

Table II. Mice body weights before and after different treatments, mice tumor weights after different treatments, and tumor inhibiting ratios.

\begin{tabular}{lcccc}
\hline \multirow{2}{*}{$\begin{array}{c}\text { Group } \\
(\mathrm{n}=5)\end{array}$} & \multicolumn{2}{c}{ Body weight $^{\mathrm{a}}(\mathrm{g})$} & $\begin{array}{c}\text { Tumor weight } \\
\mathrm{a}\end{array}$ & $\begin{array}{c}\text { Tumor inhibiting ratio } \\
(\%)\end{array}$ \\
\cline { 2 - 4 } $\mathrm{A}$ & Before treatment & After treatment & $81.9 \pm 5.97$ & --- \\
$\mathrm{B}$ & $17.68 \pm 3.67$ & $18.15 \pm 2.32$ & $81.0 \pm 6.54$ & --- \\
$\mathrm{C}$ & $19.15 \pm 2.61$ & $18.78 \pm 1.86$ & $60.5 \pm 4.89^{\mathrm{c}}$ & 26.13 \\
$\mathrm{D}$ & $18.10 \pm 3.36$ & $21.03 \pm 1.88^{\mathrm{b}}$ & $46.4 \pm 7.68^{\mathrm{c}}$ & 43.35 \\
\hline
\end{tabular}

${ }^{\mathrm{a}}$ Mean $\pm \mathrm{SD}$. ${ }^{\mathrm{P}} \mathrm{P}<0.05$ vs. group $\mathrm{A} ;{ }^{\mathrm{c}} \mathrm{P}<0.01$ vs. group A. Group A, control group; B, transfecting agent group; $\mathrm{C}, \mathrm{low}-\mathrm{dose}(0.5 \mathrm{mg} / \mathrm{kg}) \mathrm{KDR}$ siRNA group; D, high-dose (1 mg/kg) KDRsi RNA group.

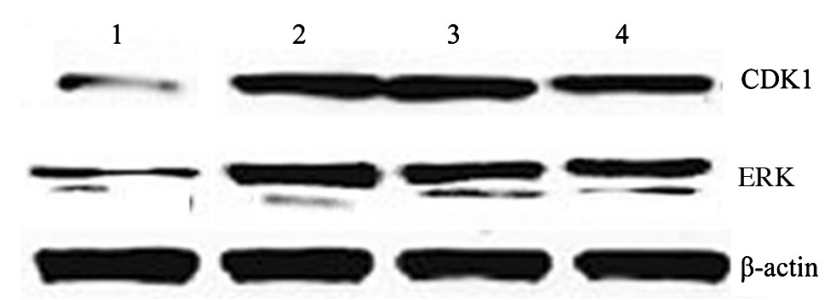

Figure 3. Western blot analysis showing the expression of ERK and CDK1 in MCF-7 cells after $48 \mathrm{~h}$ of siRNA treatment Lane 1, $100 \mathrm{nmo} / \mathrm{K}$ KDR siRNA group; lane 2, transfected with siRNAscr group; lane 3, transfected with Lipofectamine group; lane 4, non-transfected group. Compared with the control group, the expression of CDK1 and ERK protein was effectively down-regulated in groups treated with $\mathrm{KDR}$ siRNA in vitro $(\mathrm{P}<0.01)$.

treatment in MCF-7 cells; a total of $58.4 \%$ of untreated cells were in $\mathrm{G} 0 / \mathrm{G} 1$ compared with $76.2 \%$ of cells cultured with $100 \mathrm{~nm}$ siRNA.

Effect of siRNA on cell cycle-related gene expression. To further clarify the mechanism of siRNA-induced G1 cell cycle arrest, we examined the effect of siRNA on the expression of different genes involved in cell cycle control. Phosphorylated ERK and CDK1 expression was down-regulated at the protein level (Fig. 3). In addition, RNAi did not cause a non-specific down-regulation of gene expression, as determined by the B-actin control. This demonstrated that KDR siRNA transfected into MCF-7 cells successfully reduced ERK and CDK1 protein expression.

Intratumoral injection of siRNA suppressed tumor growth in the xenograft model. Tumor size in all groups was measured every 3 days. The mice in the blank control group and the transfection agent group developed larger tumors (Table II), in contrast to the mice in the low- $(0.5 \mathrm{mg} / \mathrm{kg})$ and high$(1 \mathrm{mg} / \mathrm{kg})$ dose siRNA groups, which developed much smaller tumors. On days $9,12,15,18$ and 21 , the mice in the siRNAtreated groups had a significantly smaller tumor size compared to that of those in the blank control group $(\mathrm{P}<0.05)$. As well, there was significant difference in tumor size between the lowdose siRNA group $(0.5 \mathrm{mg} / \mathrm{kg})$ and the high-dose siRNA group $(1 \mathrm{mg} / \mathrm{kg})(\mathrm{P}<0.05)$. No marked difference was observed between the transfection agent and blank control groups (P>0.05) (Fig. 4)

Down-regulation of KDR mRNA expression in vivo. KDR mRNA expression was detected in the mice in all groups, and the relative mRNA expression of KDR/GAPDH significantly decreased in the low- $(0.5 \mathrm{mg} / \mathrm{kg})$ and high- $(1 \mathrm{mg} / \mathrm{kg})$ dose siRNA groups as compared to the blank control group 


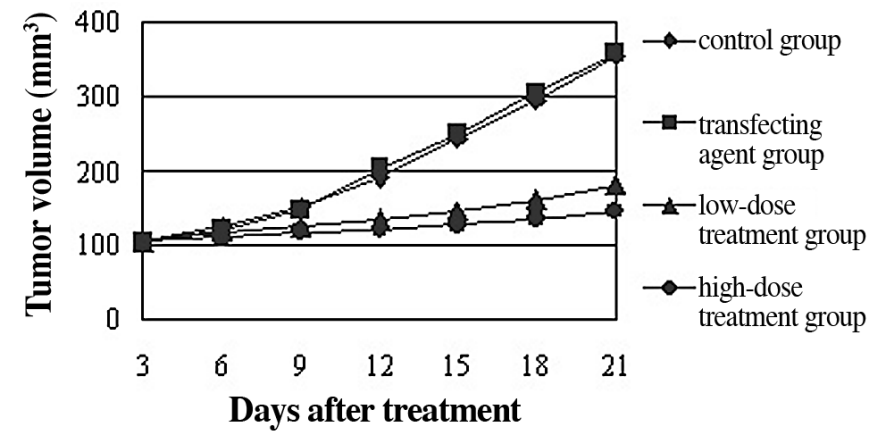

Figure 4. The growth curves of tumors in different groups after treatment (mean $\pm \mathrm{SD}, \mathrm{n}=5$ ). Tumors were measured every 3 days after treatment, and tumor volumes were calculated. Compared with the control group, the growth of tumors in groups treated with low- or high-dose KDR siRNA was obviously suppressed $(\mathrm{P}<0.05)$, as shown. Meanwhile, the growth of tumors in the highdose group was slower than in the low-dose group $(\mathrm{P}<0.05)$. There were no significant differences between the control and the transfecting agent groups $(\mathrm{P}>0.05)$.

$(\mathrm{P}<0.05)$. The relative mRNA expression of KDR/GAPDH was markedly lower in the high-dose siRNA group $(1 \mathrm{mg} / \mathrm{kg})$ than in the low-dose siRNA group $(0.5 \mathrm{mg} / \mathrm{kg})(\mathrm{P}<0.05)$. No significant difference was observed between the transfection agent group and the blank control group ( $\mathrm{P}>0.05)$ (Fig. 5).

Morphological changes in tumor tissue by histological staining. Tumor cells were arranged as nests. There was a large area of cytonecrosis in the KDR siRNA-treated groups, especially in the high-dose siRNA group (1 mg/kg) (Fig. 6D) compared to the blank control group (Fig. 6C). This indicates that the proliferation of tumor cells was inhibited.


Figure 5. KDR mRNA expression in the excised tumors of different groups. As shown, KDR siRNA effectively down-regulated the expression of KDR mRNA in excised tumors as compared with the $5 \%$ glucose control group $(\mathrm{P}<0.05)$. Lane $1,5 \%$ glucose control group; lane 2, group treated with in vivojetPEI; lane 3, group treated with low-dose KDR siRNA; lane 4, group treated with high-dose KDR siRNA.

Immunohistochemical expression of KDR. The dyed KDR protein appeared as fine brown grains. KDR staining was located in the membrane and cytoplasm of tumor cells and vascular endothelial cells. The dyed cells were spread locally or widely. KDR immunoreactivity was widely expressed in the blank control group (Fig. 6A). In contrast, in the KDR siRNA treatment group (1 mg/kg) (Fig. 6B), immunoreactivity was significantly decreased. Immunohistochemical staining rev-
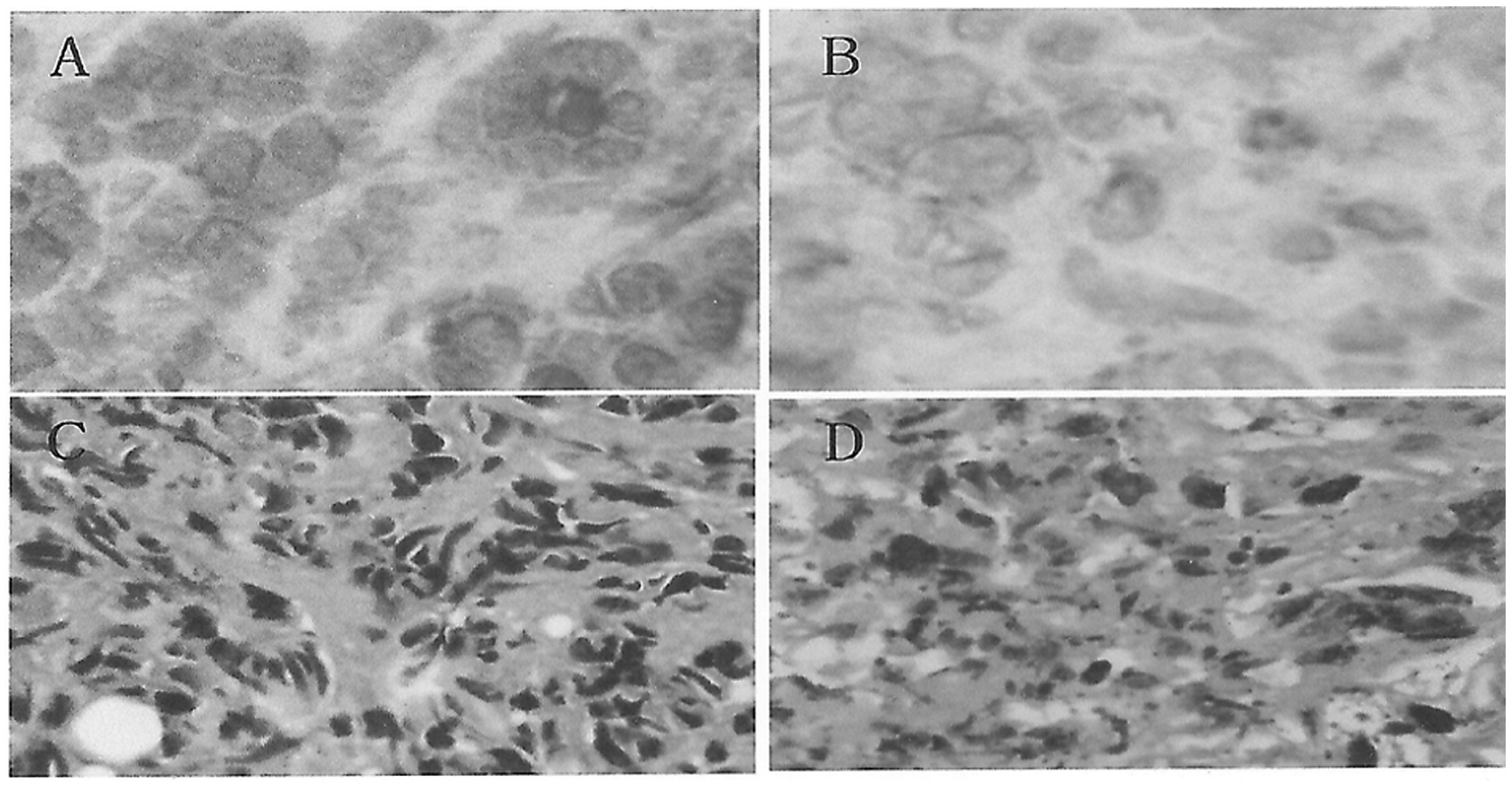

Figure 6. H\&E staining and IHC analysis in the different groups (original magnification $\mathrm{x} 400$ ). (A and C) The 5\% glucose control group and (B and D) groups treated with high-dose KDR siRNA. H\&E staining showed that there were large areas of cytoclasis in the center of tumors in the group treated with KDR siRNAs (D) compared to the control group (C). IHC analysis revealed that KDR immunoreactivity was widely expressed in the cell membrane and cytoplasm in the control group (A). In contrast, in the KDR-siRNA treatment group (B), immunoreactivity was significantly decreased. 
ealed that KDR siRNA successfully reduced KDR expression in vivo.

\section{Discussion}

In this study, two aspects of RNAi were improved: siRNA was chemically modified to strengthen its stability and ability to suppress the target gene effectively. The most important modification site was on the 2 '-OH of the ribosyl. When the $2^{\prime}-\mathrm{OH}$ of the ribosyl is substituted by $2^{2}$-O-methyl, 2'-fluorouridine (2'-FU) or 2-'fluorocytidine (2'-FC), siRNA is increasingly nuclease resistant and more stable. Experiments in vitro and in vivo found no obvious differences between 2'-F siRNA and 2'-OH siRNA in terms of their gene silencing effect (21). Moreover, their sense and antisense strands have different functions. The 3'-terminal of the antisense strand acts as a factor that recognizes and combines the target gene, so its modification markedly decreases the gene silencing effect (22). However, modification on the sense strand or a few unmatched pairs of bases in the sense strand does not influence siRNA activity. For this reason, in the present study we modified the sense strand by substituting 2'-FU for the 2'-OH of the ribosyl, while the antisense strand was not modified. In this way, our design increased the stability of siRNA in vivo, but did not affect its specificity. Polyethyleneimine (PEI) was used as a suitable transduction agent to import siRNA in vivo. PEI is a type of cationic polymer nanoparticle. Compared to cationic liposome or viral vector, it reduces toxicity to cells and increases transfection efficiency. Meanwhile, PEI avoids the potential immunogenicity and oncogenicity of viral vector transduction systems. In many studies, the PEI-siRNA nanoparticle transduction system has proven to be an ideal tool for the inhibition of specific gene expression (23), and has a promising future for clinical application.

In our in vitro experiment, MTT colorimetry detected that KDR siRNA reached a definite concentration, the silencing effect to the target gene did not increase, and the $100 \mathrm{nmol} / \mathrm{l}$ siRNA group proved to be the most effective concentration. In vivo, we used cationic polymer nanoparticle 'in vivo-jetPEI' as a transfecting agent. The in vivo experiment demonstrated that tumor-bearing nude mice treated with KDR siRNA were otherwise healthy, and that their implanted tumors grew slowly. A decrease in KDR gene expression was detected at both the mRNA and protein levels.

A number of contexts associated with decreased cell cycle progression are paradoxically associated with high rates of tumor growth. It is generally believed that cells arrested in the G1 phase evolve towards differentiation, a fate mutually exclusive with apoptosis (24). However, the question of which factors determine whether a cancer cell undergoes cell cycle arrest, differentiation or death remains unresolved. Flow cytometric analysis indicated that MCF-7 cell growth was arrested in the G1 phase of the cell cycle and decreased in the $\mathrm{S}$ phase (DNA synthesis phase) following KDR siRNA treatment. We also found phosphorylated ERK and CDK1 expression to be down-regulated at the protein level.

To conclude, our study confirmed that chemically modified KDR siRNA introduced into cancer cells or implanted tumors with a suitable transduction system effectively decreased
KDR gene expression and inhibited cellular proliferation, suggesting it may have potential as a therapeutic modality for the treatment of human breast cancer. Therefore, KDR may be a novel target for breast cancer treatment.

\section{Acknowledgements}

This work was supported by a grant from the Qingdao Science and Technology Project (no. 03-1-YN-14).

\section{References}

1. Folkman $\mathrm{J}$ : What is the evidence that tumors are angiogenesis dependent? J Natl Cancer Inst 82: 4-6, 1990.

2. Shinkaruk S, Bayle M, Lain G and Déléris G: Vascular endothelial cell growth factor (VEGF), an emerging target for cancer chemotherapy, Curr Med Chem Anticancer Agents 3: 95-117, 2003.

3. Yuriko $\mathrm{K}$ and Masaru K: Comparative integromics on VEGF family members. Int J Oncol 28: 1585-1589, 2006.

4. Ferrara N, Gerber HP and LeCouter J: The biology of VEGF and its receptors. Nat Med 9: 669-676, 2003.

5. Masood R, Cai J, Zheng T, Smith DL, Hinton DR and Gill PS: Vascular endothelial growth factor (VEGF) is an autocrine growth factor for VEGF receptor-positive human tumors. Blood 98: 1904-1913, 2001.

6. De Jong JS, van Diest PJ, van der Valk P and Baak JP: Expression of growth factors, growth-inhibiting factors, and their receptors in invasive breast cancer. II: Correlations with proliferation and angiogenesis. J Pathol 184: 53-57, 1998.

7. Vieira JM, Santos SC, Espadinha C, Correia I, Vag T, Casalou C, Cavaco BM, Catarino AL, Dias S and Leite V: Expression of vascular endothelial growth factor (VEGF) and its receptors in thyroid carcinomas of follicular origin: a potential autocrine loop. Eur J Endocrinol 153: 701-709, 2005.

8. Lacal PM, Ruddini F, Pagani E and D'Atri S: An autocrine loop directed by the vascular endothelial growth factor promotes invasiveness of human melanoma cells. Int J Oncol 27: 1625-1632, 2005.

9. Gee MF, Tsuchida R, Eichler-Jonsson C, Das B, Baruchel S and Malkin D: Vascular endothelial growth factor acts in an autocrine manner in rhabdomyosarcoma cell lines and can be inhibited with all-transretinoic acid. Oncogene 24: 8025-8037, 2005.

10. Wheeler YY, Kute TE, Willingham MC, Chen SY and Sane DC: Intrabody-based strategies for inhibition of vascular endothelial growth factor receptor-2: effects on apoptosis, cell growth, and angiogenesis. FASEB J 17: 1733-1735, 2003.

11. Bange J, Zwick E and Ullrich A: Molecular targets for breast cancer therapy and prevention. Nat Med 7: 548-552, 2001.

12. Ganz PA: The role of hormones in breast carcinogenesis: issues of relevance to female childhood cancer survivors. Med Pediatr Oncol 36: 514-518, 2001.

13. Försti A, Jin Q, Altieri A, Johansson R, Wagner K, Enquist K, Grzybowska E, Pamula J, Pekala W, Hallmans G, Lenner P and Hemminki K: Polymorphisms in the KDR and POSTN genes: association with breast cancer susceptibility and prognosis. Breast Cancer Res Treat 101: 83-93, 2007.

14. Ryden L, Linderholm B, Nielsen NH, Emdin S, Jonsson PE and Landberg G: Tumor specific VEGF-A and VEGFR2/KDR protein are co-expressed in breast cancer. Breast Cancer Res Treat 82: 147-154, 2003.

15. Yoshiji H, Gomez DE, Shibuya M and Thorgeirsson UP: Expression of vascular endothelial growth factor, its receptor, and other angiogenic factors in human breast cancer. Cancer Res 56: 2013-2016, 1996.

16. An LF and Dong Z: RNA interference - new tool for the tumor research. Chin J Oncol 27: 385-388, 2005.

17. De Souza Nascimento P, Alves G and Feidler W: Telomerase inhibition by an siRNA directed against hTERT leads to telomere attrition in HT29 cells. Oncol Rep 16: 423-428, 2006.

18. Dorsett $Y$ and Tuschl T: siRNAs applications in functional genomics and potential as therapeutics. Nat Rev Drug Discov 3: 318-329, 2004.

19. Dykxhoorn DM, Novina CD and Sharp PA: Killing the messenger: short RNAs that silence gene expression. Nat Rev Mol Cell Biol 4: 457-467 2003. 
20. Kasukabe T, Okabe-Kado J, Kato N, Sassa T and Honma Y: Effects of combined treatment with rapamycin and cotylenin A, a novel differentiation-inducing agent, on human breast carcinoma MCF-7 cells and xenografts. Breast Cancer Res 7: R1097-R1110, 2005.

21. Layzer JM, McCaffrey AP, Tanner AK, Huang Z, Kay MA and Sullenger BA: In vivo activity of nuclease-resistant siRNAs. RNA 10: 766-771, 2004.

22. Hamada M, Ohtsuka T, Kawaida R, Koizumi M, Morita K, Furukawa $\mathrm{H}$, Imanishi $\mathrm{T}$, Miyagishi $\mathrm{M}$ and Taira $\mathrm{K}$ : Effects on RNA interference in gene expression (RNAi) in cultured mammalian cells of mismatches and the introduction of chemical modifications at the 3'-ends of siRNAs. Antisense Nucleic Acid Drug Dev 12: 301-309, 2002
23. Schiffelers RM, Ansari A, Xu J, Zhou Q, Tang Q, Storm G, Molema G, Lu PY, Scaria PV and Woodle MC: Cancer siRNA therapy by tumor selective delivery with ligand-targeted sterically stabilized nanoparticle. Nucleic Acids Res 32: e149, 2004.

24. Maria GC, Nicoletta F, Mariateresa P, Lucia C, Roberta P, Ornella B and Giuseppe B: Valproic acid induces apoptosis and cell cycle arrest in poorly differentiated thyroid cancer cells. J Clin Endocrinol Metab 90: 1383-1389, 2005. 
